http://dx.doi.org/10.18778/1509-877X.02.05

\title{
DECYZJA JAKO DOWÓD W POSTĘPOWANIU PODATKOWYM
}

Streszczenie. Autorka porusza problematykę dopuszczalności wykorzystania decyzji podatkowej jako dowodu w innym postępowaniu podatkowym. Przedmiot szczegółowych rozważań stanowi kwestia uznania decyzji podatkowej za dokument urzędowy oraz tego konsekwencje. W świetle regulacji ustawowej (art. 194 Ordynacji podatkowej) decyzja, jak każdy dokument urzędowy, korzysta $\mathrm{z}$ domniemania zgodności z prawdą. To domniemanie jest wzruszalne za pomocą każdego przeciwdowodu, ponieważ najważniejsza w postepowaniu podatkowym jest realizacja zasady prawdy materialnej (art. 122 Ordynacji podatkowej).

Domniemanie wiarygodności nie obejmuje całej treści decyzji. Zgodnie z dominującą w ostatnich latach tendencją w orzecznictwie sądów administracyjnych, domniemanie zgodności z prawdą ogranicza się do sentencji decyzji. W rezultacie okoliczności faktyczne, zawarte w jej uzasadnieniu, przestały być objęte tym domniemaniem. Dla organu podatkowego ta zmiana ma istotne znaczenie praktyczne. Uniemożliwia traktowanie „cudzych” decyzji podatkowych za jedyny i wystarczający dowód przy formułowaniu rozstrzygnięcia wraz z uzasadnieniem faktycznym „własnej” decyzji.

Słowa kluczowe: dowody, postępowanie podatkowe, decyzja

\section{UWAGI WSTĘPNE}

Upraszczając rozumowanie w największy z możliwych sposobów, należy przyjąć, że celem postępowania podatkowego jest prawidłowe rozstrzygnięcie sprawy, zaś środkiem do tego prowadzącym - prawidłowo przeprowadzone postępowanie dowodowe. $\mathrm{Z}$ tego powodu w postępowaniu podatkowym

* Doktorantka Uniwersytetu Jagiellońskiego, Wydział Prawa i Administracji; agnieszka.willenberg@doctoral.uj.edu.pl. 
kluczową rolę odgrywają dowody zebrane przez organ podatkowy dla ustalenia faktów prawotwórczych. Rezultatem czynności dowodowych jest zgromadzenie materiału dowodowego, który obejmuje liczne dokumenty, zarówno prywatne, jak i urzędowe, poddane badaniu i weryfikacji. Wśród dokumentów urzędowych mogą się znaleźć decyzje podatkowe dotyczące innych podmiotów niż objęte postępowaniem podatkowy ${ }^{1}$.

Wyposażone $\mathrm{w}$ atrybuty dokumentów urzędowych, nierzadko są traktowane przez organy podatkowe jako jedyny i przesądzający dowód w sprawie, ponieważ acta publica probat se ipsa. Zjawisko to można uznać za niepokojące, jeżeli prowadzi do ograniczenia gwarancji procesowych stron postępowania podatkowego i naruszenia intuicyjnie rozumianej „sprawiedliwości proceduralnej”2. Niniejszy artykuł ma celu przybliżenie tego problemu, ze względu na wymiar praktyczny z punktu widzenia prawidłowości działania organów podatkowych w ramach postępowania podatkowego, choć bez aspiracji do wiążącego rozstrzygnięcia poruszanych kwestii.

\section{Sposób GRomadZENIA MATERIAŁU DOWODOWEGO}

W sprawach podatkowych głównym polem konfliktu podatnika i administracji skarbowej jest sposób gromadzenia materiału dowodowego. Spór ten podsyca okoliczność, że organ podatkowy jest podmiotem, który samodzielnie kieruje postepowaniem, a w konsekwencji dokonuje wyboru metod służących zrekonstruowaniu stanu faktycznego. W ten również sposób - nie bezpośrednio - także decyduje o zakresie zastosowania regulacji prawnych, odnoszących się do uprawnień procesowych strony o charakterze gwarancyjnym, przysługujących jej w związku z pozyskiwaniem dowodów i ich wykorzystaniem w postępowaniu podatkowym. Źródłem

${ }^{1}$ Jest to sytuacja bardzo częsta w przypadku postępowań podatkowych prowadzonych w zakresie zorganizowanych oszustw podatkowych, których istota opiera się na tworzeniu i działaniu łańcuchów fikcyjnych dostaw towarów.

${ }^{2}$ Trafnie ujęła to zjawisko T. Chauvin, która określiła „sprawiedliwość proceduralną" jako wartości oczekiwane lub wymagane wszędzie tam, gdzie adresaci norm mają do czynienia z pewnym uporządkowanym działaniem władzy publicznej, postępowaniem, procedurą za pomocą której władza ta realizuje swoje cele i zadania; stanowi kryterium oceny stosowania prawa w praktyce, uwzględniającej obok końcowego rozstrzygnięcia, także sposób dochodzenia do niego - zob. T. Chauvin, Prawa staja się prawem: demokratyczne procedury w stużbie wartości, [w:] Status jednostki a tendencje rozwojowe prawa, M. Wyrzykowski (red.), Warszawa 2006, s. 191. 
uprawnień podatnika oraz obowiązków organu w tym zakresie jest regulacja zawarta w Dziale IV Ordynacji podatkowej ${ }^{3}$, zatytułowanym „Postępowanie podatkowe”, przy czym odesłania ustawowe powodują, że regulacje odnoszące się do gromadzenia materiału dowodowego w sprawie, znajdują zastosowanie w kontroli podatkowej oraz kontroli celno-skarbowej (art. 292 O.p. i art. 94 ust. 1 ustawy o Krajowej Administracji Skarbowej4).

Regulacją ustawową zostaje nałożony na organ obowiązek wyznaczania zakresu postępowania dowodowego, jego kierunków i rodzaju materiału dowodowego, kierowania się uzasadnionym przekonaniem o celowości podjęcia danych czynności procesowych, wyborze form oraz trybu dokonywania czynności, a także wskazania przesłanek uzasadniających ich podjęcie. Ma to zapewnić zrealizowanie zasady zupełności postępowania dowodowego, zgodnie z obiektywizmem i zasadą prawdy materialnej, oraz z zachowaniem swobody w ocenie dowodów. Według D. Strzelca ${ }^{5}$, od roli powierzonej temu postępowaniu, tzn. czy jest nią zabezpieczenie realizacji prawa materialnego, czy także ochrona interesu indywidualnego, zależy ustalenie znaczenie gwarancji procesowych. Sam autor przyjął że gwarancje procesowe, rozumiane jako zespół norm prawa procesowego, stanowią ogół nakazów i zakazów przeznaczonych dla organu i stron, mających na celu zebranie i opracowania materiału dowodowego w sposób maksymalnie dokładny i prawidłowy, jako podstawy wydania decyzji w sprawie, dzięki czemu realizują funkcję ochronną.

Ograniczone ramy niniejszego opracowania powodują, że problem wykorzystania decyzji jako dowodu zostanie przedstawiony w perspektywie postępowania podatkowego - jurysdykcyjnego i w odniesieniu do regulacji dotyczącej sposobu zaliczania decyzji pochodzących z innych postępowań podatkowych do materiału dowodowego zgromadzonego w danej sprawie, przy zabezpieczeniu interesów strony tego postępowania. Taki sposób ujęcia tematu stanowi powód do zabrania głosu w dyskusji na temat kształtu odpowiadającego współczesnym trendom postępowania podatkowego ${ }^{6}$,

${ }^{3}$ Ustawa z dnia 29 sierpnia 1997 r. Ordynacja podatkowa (Dz.U. z 2018 r., poz. 800 ze zm.; dalej: O.p.).

${ }^{4}$ Ustawa z dnia 16 listopada 2016 r. o Krajowej Administracji Skarbowej (Dz.U. z 2018 r., poz. 508 ze zm.).

${ }^{5}$ Zob. D. Strzelec, Dowody i postępowanie dowodowe w prawie podatkowym, Warszawa 2015 , s. 218.

${ }^{6}$ Zalety stosowania $\mathrm{w}$ postępowaniu podatkowym form komunikowania się z podatnikiem, spełniających postulat sprawiedliwości proceduralnej, zostały docenione przez 
a zwłaszcza zmiany sposobu postrzegania roli procedur podatkowych oraz dezaktualizującego się przekonania, że „rola norm procesowych jest jedynie służebna i w gruncie rzeczy sprowadza się do narzucenia organowi administrującemu (podatkowemu) trybu, w jakim powinien on rozstrzygać sprawy, innymi słowy, trybu, w jakim powinien realizować swoje uprawnienia do konkretyzacji prawa, wynikające z poszczególnych stosunków materialnych ${ }^{7}$. Tymczasem pojawia się nowe rozumienie procedury i zjawisko określane jako proceduralizm ${ }^{8}$. Jak je opisała J. Helios ${ }^{9}$, mamy do czynienia w procedurze z odejściem od modelu subsumcyjnego na rzecz argumentacyjnego, od monizmu argumentacyjnego na rzecz pluralizmu, od decyzji mającej walor rozstrzygnięcia na rzecz decyzji znamionującej rozwiązanie, od klasycznej koncepcji procesu na rzecz postklasycznej, od ustawodawstwa dobrych zasad na rzecz ustawodawstwa należnych gwarancji.

Obok jakości regulacji prawnej, korygowanej orzecznictwem, na praktykę stosowania prawa ma również wpływ - wyróżnione przez W. Nykiela ${ }^{10}$ - zapewnienie zrównoważonej ochrony interesów - podatnika i budżetu państwa, oraz wskazany przez Z. Kmieciaka ${ }^{11}$ sposób stosowania obowiązujących reguł postępowania. Niewystarczające staje się operowanie tylko pojęciem standardu decyzji stosowania prawa, które oznacza, że istnieje określony zasób instytucji prawnych oraz rozwiązań techniczno-procesowych, które zapewniają pożądany standard podjętej

twórców projektu nowej Ordynacji podatkowej - zob. Uzasadnienie projektu ustawy - Ordynacja podatkowa $z$ dnia 6 października 2017 r., s. 330.

${ }^{7}$ Zob. R. Hauser, Rola przepisów procesowych $w$ realizacji norm materialnego prawa administracyjnego, [w:] Rola materialnego prawa administracyjnego a ochrona praw jednostki, Z. Leoński (red.), Poznań 1998, s. 23 i n.

${ }^{8}$ Zob. P. Kaczmarek, Materialne i proceduralne aspekty prawa. Wstęp do rozważań nad przejawami proceduralizacji w prawie europejskim, [w:] Z zagadnień teorii i filozofii prawa. Teoria prawa europejskiego, J. Kaczor (red.), „Acta Universitatis Wratislaviensis” 2005, nr 2760, s. 129 i n.

9 Zob. J. Helios, Aspekty systemowy $i$ aksjologiczny „procedur”, „Acta Universitatis Wratislaviensis" 2015, nr 3052, s. 109 i n.

${ }^{10}$ Zob. W. Nykiel, O potrzebie równowagi między uprawnieniami i obowiązkami podatnika oraz organów podatkowych, „Prawo i Podatki” 2005, nr 12, s. 25-28; W. Nykiel, Prawo do zapłaty podatku w wysokości wynikajacej z przepisów prawa, „Prawo i Podatki” 2008, nr 1, s. 1-5.

${ }^{11}$ Zob. Z. Kmieciak, Idea sprawiedliwości proceduralnej $w$ prawie administracyjnym (Założenia teoretyczne i doświadczenia praktyki), „Państwo i Prawo” 1994, nr 10, s. 62. 
rzez organ decyzji stosowania prawa ${ }^{12}$. Zdaniem P. Ostojskiego ${ }^{13}$, obecnie nie powinna już budzić wątpliwości prawdziwość tezy, że prawo nie posiada jedynie formalnej treści, lecz treść rzeczywistą - tzn. zdeterminowaną przez wartości. Owe wartości podlegają normatywizacji, wyrażane są poprzez zasady prawa, które podlegają współstosowaniu wraz z regułami prawnymi. Taką normą-zasadą jest sprawiedliwość, której proceduralna treść kształtuje w postępowaniu administracyjnym podstawowe standardy (gwarancje) odnoszące się przede wszystkim do ochrony praw jednostki w toku przygotowania oraz wydania decyzji. Dzięki tym standardom przebieg oraz rezultat postępowania powinny być w odczuciu społecznym odbierane jako sprawiedliwe.

Lapidarnie ujęła to zagadnienie M. Borucka-Arctowa ${ }^{14}$, stwierdzając, że obywatele bardzo często oceniają państwo i jego agendy w kategoriach normatywnych, przywiązując duże znaczenie do tych reguł, które w uproszczeniu dotyczą pytania ,jak?”, a nie tylko „co?”. To oznacza, że sama świadomość podatnika czym jest postępowanie dowodowe w postępowaniu podatkowym i na czym ono polega, pozostaje niewystarczająca do zaakceptowania kończącego go rozstrzygnięcia ${ }^{15}$.

Stąd, zdaniem M. Rymaszewskiego ${ }^{16}$, biorą się oczekiwania podatników, co do sprawiedliwego prowadzenia postępowania podatkowego, w którym organ podatkowy występuje nie tylko jako reprezentant interesów Skarbu Państwa, ale przede wszystkim jako rozstrzygający sprawę, przedstawiciel praworządnego państwa prawnego, które obok ochrony własnych interesów fiskalnych jest zobowiązane czuwać na tym, aby uprawnienia

12 Zob. J. Borkowski, Normy prawa materialne i formalne a pojęcie procedury administracyjnej, „Studia Prawno-Ekonomiczne” 1982, t. XXVIII, s. 41 i n., [za:] Z. Kmieciak, Idea sprawiedliwości..., s. 57.

${ }^{13}$ Zob. P. Ostojski, Sprawiedliwość proceduralna według ReNEUAL Modelu Kodeksu Postępowania Administracyjnego Unii Europejskiej, „Ruch Prawniczy, Ekonomiczny i Socjologiczny" 2017, nr 1, s. 137 i wskazana tam literatura.

${ }_{14}$ Zob. M. Borucka-Arctowa, Koncepcja sprawiedliwości proceduralnej i jej rola w okresie przemian systemu prawa - analiza teoretyczna i funkcjonalna, [w:] Dynamika wartości w prawie, K. Pałecki (red.), Kraków 1997, s. 30.

${ }^{15}$ Badanie empiryczne nad wpływem spostrzeganej sprawiedliwości proceduralnej na zachowanie podatników prowadziła m.in. M. Niesiobędzka - zob. M. Niesiobędzka, Sprawiedliwość proceduralna podatków, „Optimum. Studia Ekonomiczne” 2014, nr 4, s. $101-110$.

${ }^{16}$ Zob. M. Rymaszewski, Zasada sprawiedliwości proceduralnej w postepowaniu podatkowym, „Kwartalnik Prawa Podatkowego” 2013, nr 4, s. 35. 
obywateli nie były naruszane przez działającą w jego imieniu administrację. Jednocześnie nie sposób pomijać faktu, iż także organy podatkowe oczekują uczciwego zachowania i działania podatnika w postępowaniu podatkowym, które umożliwi im dokonanie prawidłowego rozstrzygnięcia.

Tej konstatacji odpowiada teza postawiona przez I. Bogucką ${ }^{17}$, która pojęcie sprawiedliwości proceduralnej zdefiniowała jako model procedury oparty na zbiorze wartości umożliwiających jej sprawiedliwy przebieg i warunkujących dokonanie jej oceny jako procedury uczciwej, niezależnie od rezultatu jej zastosowania. W rezultacie - zdaniem I. Boguckiej ${ }^{18}$ - miejsce zarezerwowane w postępowaniu dla sprawności (efektywności) zajmują takie wartości jak równość, wolność, bezpieczeństwo i pewność czy ochrona praw.

W podobnym duchu wypowiedział się Z. Kmieciak ${ }^{19}$, według którego sprawiedliwość proceduralna polega na takiej organizacji procesu uzyskiwania informacji, wymiany argumentacji i podejmowania decyzji, dzięki którym wynik zastosowania procedury można uznać za sprawiedliwy (uczciwy, słuszny). W ten sposób sama procedura spełnia podwójną rolę, z jednej strony stanowi kryterium oceny sprawiedliwości decyzji, a z drugiej jest także jej warunkiem ${ }^{20}$.

W sposób naturalny rodzi się pytanie o przejawy sprawiedliwości proceduralnej $\mathrm{w}$ postępowaniu. Wyjaśnienia tej kwestii podjął się m.in. Trybunał Konstytucyjny, który w jednym $z$ wyroków ${ }^{21}$ wywiódł z zasady demokratycznego państwa prawnego reguły prawne, które muszą zapewnić wszechstronne i staranne zbadanie okoliczności istotnych dla rozstrzygnięcia sprawy, gwarantować wszystkim stronom i uczestnikom postępowania prawo do wysłuchania, tj. prawo przedstawienia i obrony swoich racji, a jednocześnie umożliwiać sprawne rozpatrzenie sprawy w rozsądnym terminie.

17 Zob. I. Bogucka, [w:] System prawa administracyjnego procesowego: zagadnienia ogólne: tom I; G. Łaszczyca (red.), Warszawa 2017, s. 544 [za:] M. Bernatt, Sprawiedliwość proceduralna $w$ postępowaniu przed organem ochrony konkurencji, Warszawa 2011, s. 49; Z. Kmieciak, Idea sprawiedliwości ..., s. 55; Z. Kmieciak, Zarys teorii postepowania administracyjnego, Warszawa 2014, s. 101.

${ }^{18}$ Zob. I. Bogucka, [w:] System prawa administracyjnego procesowego: zagadnienia ogólne, t. I, G. Łaszczyca (red.), Warszawa 2017, s. 544.

${ }^{19}$ Zob. Z. Kmieciak, Idea sprawiedliwości..., s. 55 i n.

${ }^{20}$ Zob. I. Bogucka, [w:] System prawa..., s. 545.

${ }^{21}$ Zob. wyrok TK z dnia 14 czerwca 2016 r., sygn. akt 53/05 (Dz.U. Nr 118, poz. 812). 
Postępowanie dowodowe jest obszarem, który umożliwia badanie zastosowania zasady sprawiedliwości proceduralnej, nawet w tak wąskim zakresie jak sposób wykorzystania przez organ podatkowy do rozstrzygnięcia sprawy dowodu pochodzącego z innego postępowania dowodowego. Gromadzenie materiałów, zawierających informacje istotne dla wydania rozstrzygnięcia $\mathrm{w}$ sprawie podatkowej jest jednym $\mathrm{z}$ istotnych warunków odtworzenia stanu faktycznego. Na podstawie tych materiałów organ prowadzący postępowanie podatkowe bada i ocenia charakter zgromadzonych informacji ${ }^{22}$. Stan faktyczny powinien być zidentyfikowany w sposób obiektywny, to jest oparty na konkretnych faktach, sformułowanych bezstronnie, czyli oddzielonych od opinii i ocen pozaprawnych. Prawidłową decyzję podatkową można wydać jedynie wówczas, gdy organ podatkowy rozporządza całokształtem niezbędnych danych zawierających informacje, które pozostają w zgodzie ze stanem faktycznym, a więc odpowiadają prawdzie ${ }^{23}$. Prawidłowości toku postępowania dowodowego gwarantują zasady ogólne postępowania podatkowego (Rozdział I Działu IV O.p.). Obok nich funkcjonują, wyinterpretowane z przepisów ogólnych dotyczących dowodów, zasady określane jako pomocnicze $^{24}$ : zasada swobodnej oceny dowodów, zasada równej mocy dowodowej oraz stanowiące wynik uogólnienia istniejących rozwiązań normatywnych takiej jak zasada oficjalności, bezstronności ${ }^{25}$ oraz zasada bezpośredniości ${ }^{26}$. Ich zadaniem jest ochrona podatnika przed arbitralnym postepowaniem organu podatkowego. $Z$ tego punktu widzenia przedmiotem kontrowersji i osią największych sporów między podatnikami i organami jest odstępowanie przez te ostatnie od bezpośredniego przeprowadzania dowodów ${ }^{27}$ i dopuszczanie dowodów pośrednich (art. 181 O.p.). Za usprawiedliwiony powód takiego postepowania można uznać specyfikę postępowania podatkowego, w którym podstawa dokumentacyjna ma istotne znaczenie ${ }^{28}$. Wyrazem

\footnotetext{
22 Zob. A. Hanusz, Podstawa faktyczna rozstrzygnięcia podatkowego, Toruń 2006, s. 17.

${ }^{23}$ Zob. J. Zubrzycki, [w:] R. Mastalski, J. Zubrzycki, Ordynacja podatkowa: komentarz, Wrocław 2002, s. 143.

${ }^{24}$ Zob. J. Jędrośka, Polskie postępowanie administracyjne i sądowoadministracyjne, Wrocław 2003, s. 32; J. Służewski. Postępowanie administracyjne, Warszawa 1982, s. 44, [za:] D. Strzelec. Dowody i postępowanie dowodowe..., s. 140.

${ }^{25}$ Zob. B. Brzeziński, M. Kalinowski, M. Masternak, W. Morawski, Ordynacja podatkowa: komentarz praktyczny, Gdańsk 2006, s. 161.

${ }_{26}$ Zob. D. Strzelec, Zasada bezpośredniości gromadzenia materiału dowodowego w sprawach podatkowych, „Monitor Podatkowy” 2012, nr 10, s. 19-27.

${ }^{27}$ Zob. wyrok NSA z dnia 29 września 2009 r., I FSK 1916/07; www.orzeczenia.nsa.gov.pl.

${ }^{28}$ Zob. D. Strzelec, Zasada bezpośredniości..., s. 19-27.
} 
takiego podejścia ustawodawcy stał się brak bezwzględnego wymogu oparcia rozstrzygnięcia jedynie na dowodach przeprowadzonych przez organ rozstrzygający sprawę z udziałem strony ${ }^{29}$.

Stan faktyczny sprawy może zostać ustalony przez organ również na podstawie materiałów zgromadzonych $\mathrm{w}$ innych postępowaniach, $\mathrm{w}$ tym podatkowych, które po ich uznaniu za dowód w sprawie podatkowej staną się de facto dowodami w tej sprawie ${ }^{30}$. Jednocześnie nasuwa się wątpliwość co do znaczenia tej regulacji z punktu widzenia interesów strony. Sposób działania organu, w zależności od tego, czy uznaje on możliwości korzystania $\mathrm{z}$ „cudzego" materiału dowodowego za urzeczywistnienie zasady pośredniości postępowania, czy wręcz przeciwnie, traktuje to jako uzasadniony w określonych stanach faktycznych i prawnych wyjątek od zasady bezpośredniości, rodzi odmienne konsekwencje z punktu widzenia ochrony interesów strony i wpływa na ocenę całości postępowania dowodowego dokonywaną przez podatnika na podstawie ogólnego wrażenia (sprawiedliwe/niesprawiedliwe).

Ustawodawca nie wprowadził żadnych warunków, pod którymi dowody z innych postępowań mogą zostać włączone w poczet dowodów danego postępowania podatkowego, co sugeruje dopuszczalność zastosowania tej regulacji automatycznie i bezrefleksyjnie. Za takie warunki mogłyby zostać uznane okoliczności świadczące o braku możliwości lub znacznym utrudnieniu w przeprowadzeniu czynności dowodowej czy potrzeba zagwarantowania stronie czynnego udziału w takiej czynności. Ta kwestia stała się przyczynkiem do uzasadnionych rozważań doktryny i orzecznictwa nad prawidłowym i uzasadnionym działaniem organów, które nagminnie korzystając $z$ dowodów zebranych przez inne organy, ograniczają uprawnienia strony do udziału w czynności przesłuchania świadków ${ }^{31}$.

${ }^{29}$ Zob. P. Pietrasz, [w:] C. Kosikowski, L. Etel, J. Brolik, R. Dowgier, P. Pietrasz, M. Popławski, S. Presnarowicz, W. Stachurski, Ordynacja podatkowa, Warszawa 2013, s. 1014.

${ }^{30}$ Przepis art. 181 O.p. w połączeniu z art. 180 O.p. i art. 216 O.p. jest powszechnie wykorzystywany przez organy podatkowe jako podstawa włączania do akt postępowania podatkowego każdego dowodu, jaki zgodnie z prawem można pozyskać z innych postępowań; co więcej - odsyłając do dowodów przeprowadzonych w innych postępowaniach (wymienionych expressis verbis w art. 181 O.p.) ustawodawca sformułował pewne ograniczenia, co oznacza, że w przypadku pozostałych (niewymienionych) takie ograniczenia nie występują.

${ }^{31}$ Na ten temat m.in. D. Zalewski, A. Melezini, S. Golec, A. Kaźmierski, Postępowanie podatkowe: 810 wyjaśnień i interpretacji, Warszawa 2013, s. 233-240; D. Strzelec, Posługiwanie sie jako dowodem materiałami zgromadzonymi w innych postępowaniach, „Monitor 
Nie ulega wątpliwości, że z perspektywy organu podatkowego i podatnika idealną jest taka sytuacja, w której dowodzenie okoliczności mających znaczenie dla rozstrzygnięcia sprawy podatkowej odbywa się bez udziału podmiotów pośredniczących, co umożliwia korzystanie tylko z materiału dowodowego: pierwotnego, nieprzetworzonego i niezniekształconego analizą i interpretacją dokonaną przez inny organ. W rezultacie, organ prowadzący postępowanie sam może ocenić - na podstawie materiału pierwotnego - czy okoliczność została wystarczająco udowodniona, zaś strona, uczestnicząc w czynnościach dowodowych, ma poczucie wpływu na ich rezultat. Tymczasem racjonalny ustawodawca znalazł istotne powody, dla których ograniczył działanie zasady bezpośredniości. Z tego względu trudno uznać, aby jednocześnie akceptował on sytuację, w której prowadzenie postępowania zgodnie z Ordynacją podatkową (poprzez wykorzystanie materiałów $z$ innych postępowań) mogło równocześnie przepisy tej ustawy naruszać, poprzez wykluczenie lub ograniczenia działania innych zasad ${ }^{32}$.

Dopuszczenie możliwości sięgania do dowodów z innych postępowań nie oznacza przejmowania ich na grunt postępowania podatkowego w sposób bezkrytyczny. Ocena prawdziwości lub nieprawdziwości określonych twierdzeń o faktach, uzyskanych na podstawie środków dowodowych, pochodzących z materiału dowodowego zgromadzonego przez inny organ, powinna być dokonywana samodzielnie przez organ prowadzący postępowanie podatkowe, zgodnie z zasadą swobodnej oceny dowodów ${ }^{33}$. Pozostawiona organowi swoboda wyciągania logicznych wniosków z zebranego materiału dowodowego tworzy warunki sprzyjające dokonywania ustaleń prawdziwych, zgodnych z prawdą materialną i obiektywnych. Z drugiej strony, ustalenie stanu faktycznego sprawy obejmuje często żmudny i czasochłonny proces poszukiwania i odnajdywania faktów, oceny ich zgodności z prawem, wiarygodności i wartości dowodowej oraz określenia znaczenia i przydatności dla merytorycznego rozstrzygnięcia spraw ${ }^{34}$.

Podatkowy" 2008, nr 1, s. 23-30; A. Zdunek, Dopuszczenie jako dowodu w postępowaniu podatkowym materiatów zgromadzonych $w$ innych postępowaniach a zasada czynnego udziału strony w postępowaniu, [w:] Ordynacja podatkowa. Zagadnienia proceduralne, M. Popławski (red.), Białystok 2011, s. 149-161; M. Kwietko-Bębnowski, Ordynacja podatkowa: 366 wyjaśnień i interpretacji, Warszawa 2013, s. 461-466.

${ }^{32}$ Zob. wyrok NSA z dnia 3 września 2015 r., I FSK 771/14 i wyrok NSA z dnia 13 stycznia 2016 r. I FSK 1678/14; http://www.orzeczenia.nsa.gov.pl.

${ }^{33}$ Zob. S. Babiarz, B. Dauter, B. Gruszczyński, R. Hauser, A. Kabat, M. Niezgódka-Medek, Ordynacja podatkowa. Komentarz, Warszawa 2015, s. 848.

${ }^{34}$ Zob. A. Hanusz: Podstawa faktyczna.., s. 19. 
Z tego powodu, wykorzystanie treści decyzji innego organu podatkowego może znacząco ułatwić i przyspieszyć ten proces, umożliwiając sprawne rozpatrzenie sprawy w rozsądnym terminie, co nie może się jednak odbyć $\mathrm{z}$ naruszeniem praw strony do asystowania w czynnościach dowodowych.

\section{Rola i ZNACZENIE DOWODOWE DECYZJI}

Ordynacja podatkowa nie zawiera definicji „decyzji podatkowej”35. Sposób rozumienia terminu „decyzja” ukształtował się pod wpływem doktryny i orzecznictwa, co doprowadziło do wyróżnienia jej cech dystynktywnych i sformułowania w oparciu o nie definicji, umożliwiających odróżnienie decyzji od innych władczych aktów ${ }^{36}$. Jednocześnie zostały określone obowiązkowe elementy składowe decyzji, wśród których znajduje się uzasadnienia faktyczne i prawne (art. $210 \$ 1$ i $\$ 4$ O.p.). Oba stanowią integralną cześć decyzji, a ich zadaniem jest wyjaśnienie podatnikowi warunków prawnych i faktycznych dokonanego rozstrzygnięcia. Organ wykorzystuje $\mathrm{w}$ postępowaniu dowodowym decyzję pochodzącą $\mathrm{z}$ innego postepowania dowodowego, gdy w jego ocenie treść decyzji może mieć kluczowe znaczenie przy określaniu konsekwencji podatkowoprawnych dla strony tego postepowania. Ważne jest zarówno rozstrzygnięcie, w którym dokonuje się konkretyzacja prawa, jak i uzasadnienie, objaśniające tok myślenia, prowadzący do zastosowania określonego przepisu prawnego w sprawie ${ }^{37}$.

Paradoksalnie, $\mathrm{z}$ punktu widzenia interesu finansowego podatnika (strony postępowania), konfrontowanego z zebranym $\mathrm{w}$ jego sprawie materiałem dowodowym, większe znaczenie może mieć treść uzasadnienia faktycznego decyzji uznanej za dowód, ponieważ najczęściej zawiera ono

${ }^{35}$ Mimo że decyzja stanowi podstawową formę rozstrzygnięcia w postępowaniu podatkowym) prawodawca ograniczył się jedynie do stwierdzenia, że „organ podatkowy orzeka w sprawie w drodze decyzji, chyba że przepisy stanowią inaczej” (art. $207 \$ 1$ O.p.) oraz „decyzja rozstrzyga sprawę co do jej istoty lub w inny sposób kończy sprawę w danej instancji” (art. $207 \$ 2$ O.p.).

${ }^{36}$ Dowodem tego jest określenie decyzji podatkowej jako stanowiącej opartą na przepisach prawa czynność prawną właściwego organu administracji publicznej, podejmowaną w sferze zewnętrznej, kształtującą w sposób jednostronny i władczy prawa i obowiązki imiennie oznaczonego adresata $\mathrm{w}$ indywidualnej sprawie podatkowej; zob. B. Brzeziński, [w:] B. Brzeziński, M. Kalinowski, A. Olesińska, M. Masternak, J. Orłowski, Ordynacja podatkowa: komentarz, t. 2, Toruń 2007, s. 388 i n.

${ }^{37}$ Zob. B. Adamiak, J. Borkowski, Kodeks postępowania administracyjnego. Komentarz, Warszawa 2006, s. 520. 
informacje, w oparciu o które organ określa sytuację podatkowoprawną strony, najczęściej w sposób dla niej niekorzystny. Lakoniczność regulacji odnoszącej się do zawartości uzasadnienia faktycznego uzupełnia stosowanie przez organ zasady istotności (art. 180 O.p.) i prawdy obiektywnej (art. 122 O.p.). Z drugiej strony, zasada budowy zaufania od organów państwa i wywodzona z niej zasada przekonywania (art. 121 O.p.) zobowiązują organ do wyczerpującego przedstawienia materiału dowodowego, który wyjaśnia i racjonalizuje ustalenia faktyczne, przyjęte za zgodne $\mathrm{z}$ rzeczywistością. Z tego powodu w orzecznictwie często formułuje się postulaty, dotyczące jakości uzasadnienia faktycznego, wymagając - obok wszechstronnej oceny zebranego materiału dowodowego ${ }^{38}$, w tym prezentacji własnych argumentów wraz z oceną argumentów strony, także na podstawie zasad logiki i doświadczenia życiowego ${ }^{39}$ czy odniesienia się do trybu postępowania, co umożliwia stronie zrozumienie motywów organu, determinujących rozstrzygnięcie. Jako istotna wartość wskazywany jest logiczny związek i zgodność z rozstrzygnięciem, brak wywodów sprzecznych lub rozbieżnych z rozstrzygnięciem, ścisłość i dokładność, zwięzłość i prostotę ujęcia oraz kompletność motywów uzasadnienia ${ }^{40}$. W rezultacie, za niedopuszczalne uznawane są wnioski i twierdzenia organu, nieznajdujące oparcia w materiale dowodowym sprawy ${ }^{41}$.

Co do zasady, postępowaniem podatkowym rządzi zasada równej mocy dowodowej wszystkich środków dowodowych, bez ograniczeń i preferencji w wyborze dowodów, którym należy przyznać pierwszeństwo w ustalaniu istnienia określonego faktu (art. 180 O.p.) ${ }^{42}$. Mimo to, prawodawca dopuścił od niej wyjątki, nadając szczególne znaczenie m. in. dokumentowi urzędowemu (art. 194 O.p.) ${ }^{43}$, choć nie został on wprost wymieniony wśród

${ }^{38}$ Zob. wyrok NSA z dnia 20 stycznia 2010 r., I FSK 1877/08; http://www.orzeczenia. nsa.gov.pl.

${ }^{39}$ Zob. wyrok WSA z dnia 28 kwietnia 2010 r., I SA/Op 156/10; http://www.orzeczenia.nsa.gov.pl.

${ }^{40}$ Zob. wyrok WSA z dnia 13 kwietnia 2005 r., II SA/Gd 3959/01; http://www.orzeczenia.nsa.gov.pl.

${ }^{41}$ Zob. wyrok WSA z dnia 14 kwietnia 2005 r., III SA/Wa 180/05; http://www.orzeczenia.nsa.gov.pl.

42 Zob. B. Adamiak, J. Borkowski, R. Mastalski, J. Zubrzycki, Ordynacja podatkowa. Komentarz, Wrocław 2006, s. 783.

${ }^{43}$ Zob. wyrok NSA z dnia 28 lipca 2011 r., I FSK 1489/10; drugim wyjątkiem jest „rzetelna i niewadliwa księga podatkowa” (art. 193 O.p.). 
rodzajów dowodów (art. 181 O.p. $)^{44}$. Wobec braku definicji ${ }^{45}$ powszechnie przyjmuje się, że stanowi on utrwalony na piśmie przejaw wiedzy lub woli organu państwowego ${ }^{46}$, spełniający warunki odpowiedniej formy i upoważnionego autora ${ }^{47}$. Konfrontacja regulacji ustawowych, dotyczących dokumentu urzędowego i decyzji podatkowej, prowadzi do wniosku, że nic nie stoi na przeszkodzie uznaniu każdej decyzji podatkowej za dokument urzędowy, podczas gdy nie każdy dokument urzędowy może być uznany za decyzję podatkową. W rezultacie, zawarte w niej ustalenia stanowią element stanu faktycznego sprawy, któremu towarzyszy konkretna moc dowodowa (siła przekonywania) - formalna i materialna ${ }^{48}$, przy czym

${ }^{44}$ Zob. S. Babiarz, B. Dauter, B. Gruszczyński, R. Hauser, A. Kabat, M. Niezgódka-Medek, Ordynacja podatkowa: komentarz, s. 886.

45 Termin ten nie został jednoznacznie skonkretyzowany w Ordynacji podatkowej, a jedyna jego legalna definicja została zamieszczona w ustawie o dostępie do informacji niejawnych - zob. art. 6 ustawy z dnia 6 września 2001 r. o dostępie do informacji publicznej (Dz.U. z 2016 r., poz. 1764) w brzmieniu: „dokumentem urzędowym w rozumieniu ustawy jest treść oświadczenia woli lub wiedzy, utrwalona i podpisana w dowolnej formie przez funkcjonariusza publicznego w rozumieniu Kodeksu Karnego, w ramach jego kompetencji, skierowana do innego podmiotu lub złożona do akt sprawy"; dokument urzędowy może występować w postępowaniu podatkowym w jednej z dwóch ról - jako środek dowodowy albo źródło dowodu; w pierwszym przypadku o jego wartości decyduje treść pojęciowa i jej znaczenie dowodowe dla rozstrzygnięcia sprawy; w drugim - zostaje zredukowany do nośnika informacji o określonej treści, [za:] A. Hanusz: Dopuszczalność dowodu z dokumentu w postępowaniu sq̨dowoadministracyjnym, [w:] Ksiega Jubileuszowa Profesora Ryszarda Mastalskiego. Stanowienie i stosowanie prawa podatkowego, W. Miemiec (red.), Wrocław 2009, s. 205; co do zasady „dokument urzędowy” jako „akt pisemny, stanowiący wyrażenie określonych myśli lub wiadomości” jest uważany za środek dowodowy - zob. B. Brzeziński, M. Kalinowski, A. Olesińska, M. Masternak, J. Orłowski: Ordynacja podatkowa..., s. 309.

${ }^{46}$ Także przejaw „woli i wiedzy” instytucji lub organizacji, które na podstawie odrębnych przepisów mają prawo do wydawania określonych dokumentów - na podstawie $₫ 2$ art. 194 O.p.

${ }^{47}$ Zob. wyrok NSA z 3 listopada 2010 r., I GSK 426/09; http://www.orzeczenia.nsa. gov.pl.

${ }^{48}$ Moc dowodowa formalna (zewnętrzna) wynika z tego, że określony dokument został wydany przez podmiot uprawniony i skierowany na zewnątrz w celu wywołania pożądanego skutku. Z kolei materialna moc dowodowa (wewnętrzna) jest związana z treścią danego dokumentu i dotyczy znaczenia oraz skuteczności prawnej oświadczenia zawartego w dokumencie i jego komunikatywności w kontekście postępowania dowodowego oraz relewantności z punktu widzenia tematu dowodowego; wyrok NSA z dnia 18 listopada 2011 r., I GSK 544/11; http://www.orzeczenia.nsa.gov.pl. 
pierwsza nie przesądza o drugiej, tj. nie decyduje o ważności, skuteczności i prawdziwości treści dokumentu ${ }^{49}$.

Znaczenie dowodowe decyzji dodatkowo wzmacnia atrybut zwiększonej (szczególnej) mocy dowodowej, którego źródłem są przysługujące dokumentowi urzędowemu domniemania ustawowe (art. 194 § 1 O.p. $)^{50}$. Domniemanie nie jest dowodem, ale raczej metodą dowodzenia ${ }^{51}$. W literaturze przyjmuje się, że w przypadku ustanowienia domniemań prawnych normy prawa narzucają uczestnikom postępowania podatkowego (organowi i stronie) ocenę dokumentów urzędowych, bez względu na ich stosunek do rzeczywistości, logiki, praktyki gospodarczej, doświadczenia życiowego itd. W tym zakresie domniemania prawne łamią zasadę swobodnej oceny dowodów, a w konsekwencji uniemożliwiają lub utrudniają dotarcie do prawdy materialnej, na której powinna być zbudowana podstawa faktyczna każdego rozstrzygnięcia podatkowego ${ }^{52}$. Z tego wynika, że organ jest związany normatywną oceną dokumentu urzędowego, co oznacza, że nie może swobodnie oceniać jego treści, tzn. za udowodnione musi przyjąć to, co wynika wprost $\mathrm{z}$ dokumentu i nie może odrzucić (zakwestionować) istnienia m.in. określonego faktu stwierdzonego w dokumencie urzędowym przez inny organ. Treść dokumentu urzędowego podlega jednak ocenie organu podatkowego, który jest zmuszony co najmniej zapoznać się z treścią dokumentu, aby sformułować własne wnioski, mogące mieć znaczenie dla sprawy. Niemniej ocena ta nie może się wiązać $\mathrm{z}$ wartościowaniem i nieskrępowaną weryfikacją dokumentu urzędowego ${ }^{53}$. Na tej podstawie może

${ }^{49}$ Zob. wyrok NSA z dnia 3 lutego 2006 r., I OSK 387/05; http://www.orzeczenia.nsa. gov.pl.

${ }^{50}$ Ordynacja podatkowa nie reguluje expressis verbis dopuszczalności przyjmowania domniemań jako metody dowodzenia, choć ustanawia w przepisach szczegółowych domniemania prawne np. domniemanie istnienia pełnomocnictwa (art. 138b $\$ 3$ O.p.), domniemanie doręczenia pisma (art. $150 \$ 4$ O.p.), domniemanie zgodności z prawdą dokumentu urzędowego (art. 194 O.p.); domniemanie prawne wynika z przepisu, który nakazuje przyjęcie faktu poszukiwanego na podstawie innego faktu, [za:] B. Adamiak, J. Borkowski, Postępowanie administracyjne i sądowoadministracyjne, Warszawa 2013, s. 213.

${ }^{51}$ A. Szopieraj-Kowalska: Dowody i postępowanie dowodowe według kodeksu postępowania administracyjnego i ordynacji podatkowej, http://kpsw.edu.pl/pobierz/wydawnictwo/miscellanea/nr2/kowalska_dowody_i_postepo wanie.pl, s. 218.

${ }^{52}$ Zob. A. Hanusz, Dowód z dokumentu w postępowaniu podatkowym, [w:] Ex iniuria non oritur ius. Ksiega ku czci Profesora Wojciecha Łączkowskiego, A. Gomułowicz (red.), Poznań 2003, s. 319.

${ }^{53}$ Zob. P. Pietrasz, [w:] C. Kosikowski, L. Etel, J. Brolik, R. Dowgier, P. Pietrasz, M. Popławski, S. Presnarowicz, W. Stachurski, Ordynacja podatkowa. Komentarz, s. 1065. 
się wydawać, że domniemanie prawne ułatwia postępowanie dowodowe, ponieważ zwalnia go (lub stronę postępowania) od ciężaru przeprowadzenia dowodu, co ma znaczenie z punktu widzenia ekonomiki procesowej, tym bardziej że ogólna reguła dotycząca domniemań wskazuje, że w sytuacjach wątpliwych należy wniosek wynikający z domniemania utrzymać, a nie odrzucićs ${ }^{54}$.

Domniemania odnoszące się do dokumentu urzędowego (art. 194 § 1 O.p.) obejmują również decyzję podatkową. W ten sposób decyzja korzysta z domniemania prawdziwości (autentyczności) zakładającego, że pochodzi od organu, który ją wystawi ${ }^{55}$ oraz domniemania zgodności z prawdą (wiarygodności) tego, co zostało w niej urzędowo stwierdzone ${ }^{56}$. Co ważne, domniemania te odnoszą się do formalnej mocy dowodowej dokumentu urzędowego ${ }^{57}$, dzięki czemu nakazują traktowanie jako udowodnioną treść dokumentu, natomiast nie rozstrzygają o znaczeniu dokumentu dla wyniku sprawy. Ta ostatnia kwestia winna być przedmiotem samodzielnej oceny organu podatkowego, przy uwzględnieniu zasad prawdy materialnej (art. 122 O.p.) i zupełności materiału dowodowego (art. $187 \$ 1$ O.p. $)^{58}$, z zachowaniem perspektywy ochrony uprawnień procesowych strony.

\section{GWARANCJE OCHRONY PRAW PODATNIKA}

Wykorzystanie przez organ dowodu, jakim jest decyzji pochodząca $\mathrm{z}$ innego postępowania dowodowego, korzystająca $\mathrm{z}$ atrybutu domniemania zgodności z prawdą, pozwala organowi na uznanie wynikających z niej faktów za udowodnione ${ }^{59}$. Dzięki temu czyni się zadość zasadzie ekono-

${ }^{54}$ Zob. H. Dolecki, Ciężar dowodu w polskim prawie cywilnym, Warszawa 1998, s. 152.

${ }_{55}$ Domniemanie autentyczności dokumentu urzędowego nie zostało wyraźnie ustanowione w Ordynacji podatkowej, jednak można je wywieźć z treści art. $194 \$ 1$ O.p; brak takiego domniemania powodowałby obowiązek badania przez organ podatkowy każdego dokumentu urzędowego, czy pochodzi od podmiotu, który go wystawił - zob. B. Brzeziński, M. Kalinowski, A. Olesińska, M. Masternak, J. Orłowski, Ordynacja podatkowa..., s. 310.

${ }^{56}$ Zob. B. Adamiak, J. Borkowski, Kodeks postępowania administracyjnego. Komentarz, Warszawa 2012, s. 341.

${ }^{57}$ Zob. B. Adamiak, J. Borkowski, R. Mastalski, J. Zubrzycki, Ordynacja podatkowa. Komentarz, Wrocław 2006, s. 720.

${ }^{58}$ Zob. S. Babiarz, B. Dauter, B. Gruszczyński, R. Hauser, A. Kabat, M. Niezgódka-Medek, Ordynacja podatkowa. Komentarz, s. 888.

${ }^{59}$ Zob. wyrok NSA z dnia 12 marca 2013r., II FSK 1427/11; http://www.orzeczenia.nsa. gov.pl. 
miki procesowej (art. 125 O.p.), chroniąc organ przed zarzutem zbędnej zwłoki czy opieszałości w podejmowaniu i prowadzeniu czynnościach procesowych. Jednocześnie organ podatkowy nie ma obowiązku poprzestania na treści decyzji ${ }^{60}$, co jest konsekwencją faktu, że swobodna ocena dowodów przejawia się w dwóch płaszczyznach: wyboru środków dowodowych oraz ich oceny ${ }^{61}$. Stąd należy uznać za nieznajdujące podstaw prawnych i $\mathrm{z}$ tego powodu niedopuszczalne, ujawniające się $\mathrm{w}$ trakcie postepowań podatkowych przekonanie organów, że moc dowodowa decyzji podatkowych wydanych przez inne organy jest absolutna ${ }^{62}$. Tymczasem strona nie jest wobec domniemań bezbronna, ponieważ domniemania są wzruszalne $e^{63}$, co oznacza procesową dopuszczalność ich podważenia i obalenia (art. $194 \$ 3$ O.p.), ze wszystkimi tego konsekwencjami ${ }^{64}$. Podatnik ma prawo domagać się od organu przeprowadzenia przeciwdowodu, podważającego niekorzystne dla niej domniemanie autentyczności lub prawdziwości dokumentu urzędowego (art. 188 O.p.), zwłaszcza gdy dowód dotyczy tezy dowodowej korzystnej dla podatnika ${ }^{65}$. Z tego względu ciężar obalenia domniemania spoczywa na podatniku, a zatem inicjatywa w tej kwestii nie może być przejęta na organ podatkowy ${ }^{66}$. Brak jakichkolwiek przesłanek,

${ }^{60}$ Zob. wyrok NSA z dnia 19 kwietnia 2012 r., I FSK 956/11; http://www.orzeczenia. nsa.gov.pl.

${ }^{61}$ Zob. D. Strzelec, Dowody i postepowanie dowodowe..., s. 198 i 199.

${ }^{62}$ Skłonność organów administracyjnych do bezkrytycznego przyjmowania dokumentów urzędowych jako dowodów w sprawie była powodem częstego przypominania przez sądy o możliwościach przeprowadzenia przeciwdowodu, [za:] P. Przybysz: Kodeks postępowania administracyjnego: komentarz, Warszawa 2013, s. 251.

${ }^{63}$ Inaczej „proste” w odróżnieniu od domniemań prawnych niezbitych, niedających się obalić przeciwdowodem, bo taki przeciwdowód jest zakazany, [za:] B. Adamiak, J. Borkowski, Postępowanie administracyjne i sądowoadministracyjne, Warszawa 2013, s. 213.

${ }^{64} \mathrm{~W}$ przypadku obalenia domniemania zgodności z prawdą, dokument urzędowy jest traktowany jak dokument prywatny, a zatem jego treść podlega swobodnej ocenie organu podatkowego, który w efekcie może go uwzględnić bądź odrzucić (pominąć). Natomiast obalenie prawdziwości dokumentu urzędowego powoduje, że dokument urzędowy nie może zostać wykorzystany jako dowód w postępowaniu podatkowy; zob. D. Zalewski, A. Melezini, S. Golec, A. Kaźmierski, Postępowanie podatkowe..., s. 513; B. Brzeziński, [w:] B. Brzeziński, M. Kalinowski, A. Olesińska, M. Masternak, J. Orłowski, Ordynacja podatkowa..., s. 310 .

${ }^{65}$ Zob. wyrok NSA z dnia 27 czerwca 2012 r., I FSK 1344/11, http://www.orzeczenia. nsa.gov.pl.

${ }^{66}$ Zob. wyrok NSA z dnia 21 lutego 2012 r., I FSK 734/11; http://www.orzeczenia. nsa.gov.pl. 
wskazujących dopuszczalne formy kontrdowodów, otwiera możliwość przeprowadzenia każdego dowodu, przy czym gołosłowne twierdzenia strony mogą zostać uznane za niewystarczające w tym zakresie ${ }^{67}$.

Pogląd, z którego wynika, że poszukiwanie prawdy materialnej powinno być dokonywane nawet wbrew domniemaniu zgodności z prawdą ${ }^{68}$ otwiera przez stroną możliwości podważenia domniemania w odniesieniu do każdej decyzji, wydanej przez inny organ i włączonej do materiału dowodowego danej sprawy. Jest to tym bardziej uzasadnione, że specyfika decyzji jako dowodu polega głównie na tym, że zawiera elementy stanu faktycznego, ustalone przez inny organ i przez ten organ ocenione z punktu widzenia ich skutków podatkowoprawnych ${ }^{69}$.

Ten aspekt faktograficzny decyzji bywa jednak instrumentalnie wykorzystywany przez organ w razie zasadniczego konfliktu interesów, jaki pojawia się w sytuacji podatkowej: interes finansowy państwa a interes podatnika. Z tego powodu, w praktyce organów podatkowych, do powszechnych należy sytuacja, w której strona postępowania podatkowego kwestionuje treść decyzji podatkowej. Zwłaszcza w przypadku decyzji wydanej w postępowaniu podatkowym dotyczącym jej kontrahenta oraz uznanej przez organ za główny i rozstrzygający dowód w sprawie, którego znaczenie dowodowe polega głównie na tym, że w sposób niekorzystny wpływa na sytuację podatkowoprawną strony, pogarszając ją znacząco. W interesie strony jest podważenie treść decyzji niezgodnej ze stanem rzeczywistym, poprzez udowodnienie albo chociaż uprawdopodobnienie faktów, które podważałyby stan rzeczywisty opisany w decyzjach ${ }^{70}$. Materialny aspekt dokumentu urzędowego, jakim jest decyzja, może być kwestionowany wszelkimi dowodami (art. $194 \$ 3$ O.p.) $)^{71}$. Pozostaje pytanie, jak potraktować aspekt formalny decyzji, która jest nietypowym dokumentem urzędowym, ze względu na obecne w procedurze zasady jej trwałości i stabilności. Wydaje się, iż skuteczne przeprowadzenia przeciwdowodu wobec domniemania zgodności z prawdą, przysługującego decyzji podatkowej, nie musi grozić naru-

\section{${ }^{67}$ Tamże.}

${ }^{68}$ Zob. A. Hanusz: Podstawa faktyczna..., s. 20.

${ }^{69}$ Najlepiej to zjawisko odzwierciedla model podatku od towarów i usług, oparty na mechanizmie odliczenia podatku pobranego w poprzednich etapach obrotu.

${ }^{70}$ Zob. wyrok NSA z dnia 12 marca 2013 r., II FSK 1427/11; http://www.orzeczenia. nsa.gov.pl.

${ }^{71}$ Zob. wyrok NSA z 18 listopada 2011 r., I GSK 544/11 i wyrok NSA z dnia 9 listopada 2011 r., I GSK 231/11; http://www.orzeczenia.nsa.gov.pl. 
szeniem tych zasad. Podważenie formalnej mocy dowodowej dokumentu urzędowego, w postaci decyzji ostatecznej, wymaga wszczęcia i przeprowadzenia stosownej procedury, związanej z jego weryfikacją (art. 128 O.p.).

W przypadku ostatecznej decyzji administracyjnej przyjmuje się, że dopóki dokument urzędowy, będący decyzją administracyjną, znajduje się w obiegu prawnym, dopóty należy go oceniać zgodnie z jego treścią. Wątpliwość co do treści takiego dokumentu powinna stanowić podstawę uruchomienia procedury nadzwyczajnej, bowiem nie do pogodzenia z praworządnością jest sytuacja, gdy dwa organy, przy wydawaniu decyzji administracyjnej, oceniają sprzecznie ten sam stan faktyczny ${ }^{72}$. Wydaje się jednak, że wymóg zastosowania procedury nadzwyczajnej jako jedynej drogi podważenia domniemania wiarygodności decyzji dotyczy głównie postępowań, których przedmiotem są tożsame stosunki prawnomaterialne, mogące stanowić przedmiot decyzji związanych (zależnych) ${ }^{73}$. W pozostałych przypadkach pierwszeństwo należy przyznać zasadzie prawdy materialnej i swobodzie oceny materiału dowodowego, umożliwiającym organowi samodzielne rozstrzyganie zagadnień występujących w sprawie. Odrębną kwestią jest zagadnienie stabilności decyzji podatkowej. W procedurze podatkowej decyzją jest związany wyłącznie organ, który ją wydał (art. 212 O.p.). Ustawodawca nie przewidział dla decyzji podatkowej instytucji prawomocności materialnej (tzw. prejudykatu ${ }^{74}$ ) w znaczeniu odpowiadającym prawomocności orzeczeń sądowych ${ }^{75}$, co oznacza, że taką decyzją nie są związane inne

${ }^{72}$ Zob. P. Pietrasz, [w:] C. Kosikowski, L. Etel, J. Brolik, R. Dowgier, P. Pietrasz, M. Popławski, S. Presnarowicz, W. Stachurski: Ordynacja podatkowa. Komentarz, s. 1067 i 1068.

${ }^{73}$ Zob. wyrok WSA z dnia 12 marca 2004 r., III SA 2100/02 oraz wyrok NSA z dnia 30 stycznia 2008 r., II FSK 1471/06; http://www.orzeczenia.nsa.gov.pl.

${ }^{74}$ Prejudycjalność charakteryzuje określony stosunek zależności, a jej konieczną cechą jest decydujące (przesądzające) znaczenie, jakie ma rozstrzygnięcie jednej kwestii dla rozstrzygnięcia innej kwestii; zob. wyrok SN z dnia 15 stycznia 2015 r., IV CSK 181/14; http://www.sn.pl/orzeczenia.

${ }^{75}$ Zgodnie $\mathrm{z}$ art. $365 \S 1$ Kodeksu postępowania cywilnego orzeczenie prawomocne wiąże nie tylko strony i sąd, który je wydał, lecz również inne sądy oraz inne organy państwowe i administracji publicznej, a w przypadkach przewidzianych w ustawie także inne osoby; z tego powodu ma zastosowanie także w postępowaniu podatkowym, przy czym stanowi lex specialis w stosunku do art. 194 O.p.; wobec braku analogicznej regulacji odnośnie do prawomocnych wyroków karnych - na podstawie art. 11 ustawy z dnia 30 sierpnia 2002 r. Prawo o postępowaniu przed sądami administracyjnymi (Dz.U. z 2016 r., poz. 718 ze zm.) - przyjmuje się pośrednie związanie organów podatkowych ustaleniami wydanego w postępowaniu karnym prawomocnego wyroku skazującego; zob. wyrok NSA z dnia 16 lutego 2011 r., I FSK 255/10; http://www.orzeczenia.nsa.gov.pl. 
organy (w tym podatkowe), a jedynie organ, który ją wydał. Co więcej - także organ, który ją wydał nie jest nią związany w innej sprawie.

$\mathrm{Z}$ punktu widzenia organu, jako działanie contra legem należy ocenić uznanie decyzji za dowód, dokonane jedynie z pobudek formalnych, zwłaszcza gdy wnioski w niej zawarte ograniczają jego swobodę dowodową. Z jednej strony, nieuznanie faktu stwierdzonego w dokumencie urzędowym, bez przeprowadzenia przeciwdowodu ${ }^{76} \mathrm{z}$ inicjatywy strony lub $\mathrm{z}$ urzędu, stanowi naruszenie prawa procesowego. $\mathrm{Z}$ drugiej, odebranie dokumentowi waloru „urzędowego" każdorazowo wymaga wnikliwego uzasadnienia ${ }^{77}$, ponieważ domniemanie wiąże organ dopóki nie zostanie obalone. W tym miejscu pojawia się kwestia, w jakim zakresie uznana za dowód decyzja wiąże organ. Treść decyzji tworzą łącznie dwie części: rozstrzygniecie i uzasadnienie, co prowadzi do wniosku, że domniemanie zgodności z prawdą obejmuje nie tylko sentencję wydanej decyzji, ale również fakty stwierdzone w jej uzasadnieniu, ponieważ decyzja podatkowa w całości ma charakter sprawozdawczy (narratywny) $)^{78}$. Od pewnego czasu można dostrzec zmianę w stanowisku zwłaszcza orzecznictwa, polegającą na objęciu domniemaniem zgodności z prawdą jedynie sentencji decyzji, uznanych za dowód i włączonych do akt sprawy. Z dużym prawdopodobieństwem można stwierdzić, że zmiana dokonała się pod wpływem przypadków traktowania przez organy podatkowe decyzji kończących inne postępowania (nieostatecznych i ostatecznych) za dowód jedyny i wystarczający nie tylko w zakresie rozstrzygnięcia, ale również elementów składowych uzasadnienia faktycznego. Wyrazem tego trendu jest stanowisko orzecznictwa, zgodnie z którym domniemanie wiarygodności decyzji, jako dokumentu urzędowego, wcale nie oznacza, że organ podatkowy jest związany ustaleniami faktycznymi zawartymi w uzasadnieniu decyzji, bowiem obejmuje ono sentencję decyzji, a nie motywy rozstrzygnięcia, czy ocenę materiału dowodowego dokonaną przez organ ją wydający. Zwłaszcza

${ }^{76}$ Zob. wyrok NSA z dnia 30 stycznia 2008 r., II FSK 1135/07; http://www.orzeczenia. nsa.gov.pl.

${ }_{77}$ Zob. W. Bochenek, [w:] Kodeks postępowania administracyjnego: komentarz dla praktyków, A. Mudrecki (red.), Gdańsk 2008, s. 183.

${ }^{78}$ Takiemu myśleniu długo sprzyjało stanowisko orzecznictwa, zgodnie z którym dla potrzeb domniemania należy odróżnić w dokumencie urzędowym treść „zaświadczającą” od pozostałej treści dokumentu oraz właściwy zakres „zaświadczenia”, bowiem tylko ta część dokumentu jest objęta domniemaniem, zaś pozostała podlega ocenie na zasadach ogólnych - wyrok SN z dnia 12 lutego 2010 r., I CSK 340/09 oraz wyrok SN z dnia 4 czerwca 2014 r. II CSK 460/13; http://www.sn.pl/orzecznictwo. 
dotyczy to sytuacji, gdy podstawa faktyczna takiej decyzji jest wykorzystywana jako jedyny (lub główny) dowód w sprawie, i nawet wówczas, gdy umożliwia to skrócenia i uproszczenie postępowania dowodowego ${ }^{79}$.

Ograniczenie przez orzecznictwo domniemania wiarygodności decyzji tylko do jej sentencji stawia pod znakiem zapytania kwestię traktowania tego dokumentu jako zintegrowanej formalnie i materialnie całości, niemniej główną przyczyną takiego stanowiska było nadużywanie przez organy zasady pośredniości, prowadzące do ograniczania gwarancji procesowych strony. Mimo początkowego podążania przez judykaturę w kierunku ograniczenia zasady bezpośredniości w procedurze podatkowe ${ }^{80}$, ostatecznie dowody pośrednie zostały uznane za niewystarczające. Powodem tego stała się praktyka organów, sprzeniewierzająca się podstawowym zasadom postępowania dowodowego: prawdy obiektywnej, zupełności materiału dowodowego czy swobody jego oceny. Przyznanie, że organ jest związany co najmniej ostateczną decyzją, wydaną w innej sprawie, prowadził do wniosku o zbędności całego postępowania dowodowego. Nie ma normy prawnej, nakazującej związanie ustaleniami zawartymi w ostatecznej decyzji organu w stosunku do innego podmiotu nawet, gdy przedmiotowo sprawa ta związana jest $\mathrm{z}$ postępowaniem $\mathrm{w}$ innej sprawie ${ }^{81}$. Organy podatkowe winny więc oceniać wszechstronnie zebrane w sprawie materiały dowodowe, nie będąc związanymi oceną i ustaleniami przyjętymi przez inne organy ${ }^{82}$.

79 Zob. wyrok WSA z 3.04.2014 r., III SA/Wa 2042/13; http://www.orzeczenia.nsa. gov.pl.; stanowi to w pewnym sensie nawiązanie do koncepcji zakresu związania mocą wiążącą wyroku sądowego, która ogranicza się do sentencji i nie obejmuje uzasadnienia, czyli przesłanek faktycznych i prawnych przyjętymi za podstawę wyroku, gdyż zakresem prawomocności materialnej wyroku jest objęty tylko ostateczny wynik rozstrzygnięcia a nie jego przesłanki; oczywiście, nie jest właściwa sytuacja, w której analogiczne stany faktyczne zostają odmiennie ocenione przez różne sądy, niemniej nie uzasadnia to poszerzania zakresu mocy wiążącej prawomocnego wyroku, natomiast nakłada na sąd rozpoznający sprawę później obowiązek szczególnie wnikliwego i rozważnego osądu, uwzględniającego także argumenty, które prowadziły do odmiennych wniosków oraz wyjaśnienia przyczyn odmiennej oceny - zob. wyrok SN z dnia 15 stycznia 2015 r., IV CSK 181/14; http://www.sn.pl/orzecznictwo.

${ }^{80}$ Zob. wyrok WSA z dnia 25 czerwca 2008 r., I SA/Op 23/08, wyrok NSA z dnia 10 czerwca 2010 r., I GSK 857/09 i wyrok NSA z dnia 29 września 2009 r., I FSK 1916/07; http://www.orzeczenia.nsa.gov.pl.

${ }^{81}$ Zob. wyrok WSA z dnia 12 grudnia 2013 r., III SA/Wa 1314/13; http://www.orzeczenia.nsa.gov.pl.

82 Zob. wyrok WSA z dnia 3 kwietnia 2014 r., III SA/Wa 2042/13; http://www. orzeczenia.nsa.gov.pl; związanie organu oznacza brak możliwości pominięcia własnego 
Kontrowersje wokół wykorzystania materiałów (w tym decyzji), pochodzących $z$ innych postepowań podatkowych, wynikły głównie na tle korzystania przez organy z decyzji podatkowych, których rozstrzygnięcia opierały się głównie na treści zeznań świadków. W wielu przypadkach formalistyczne ${ }^{83}$ podejście organów podatkowych do materiałów dowodowych, prowadziło do rażącego naruszenia zasady zapewnienia stronie czynnego udziału w postępowaniu podatkowym poprzez pozbawienie jej możliwości zadawania pytań świadkom i skonfrontowania się nimi „na żywo”. W odróżnieniu od w miarę jednolitego stanowiska judykatury i doktryny w przedmiocie dopuszczalności wykorzystywania „nieosobowych" środków dowodowych z innych postępowań, w kwestii włączania do postępowania podatkowego „osobowych” źródeł dowodowych oraz włączania dowodów z postępowania toczącego się wobec innego podmiotu, te stanowiska są odmienne ${ }^{84}$.

Szczegółowe rozważnie tej kwestii wykracza poza ramy niniejszego opracowania. Najważniejsza wydaje się konstatacja, że organ winien przeprowadzić dowody ponownie w każdym przypadku, gdy podatnik stwierdza i wskazuje sensowność takiego żądania. W tym przypadku wystarczy, aby strona wyraziła chęć zadania świadkom dodatkowych pytań

rozstrzygnięcia, które ukształtowało prawa i obowiązki oraz konieczność uwzględnienia tego stanu w innych postępowaniach, które organ prowadzi, pozostających w związku podmiotowo-przedmiotowym z materią sprawy rozstrzygniętej choćby nieostateczną decyzją, ale już funkcjonującą w obiegu prawnym i z niego nie wyeliminowaną.

${ }^{83}$ Problemem formalizmu w działaniu administracji publicznej zajmuje się m.in. I. Niżnik-Dobosz, według której normy postepowań administracyjnych są zasadniczym przejawem sformalizowania działalności organów administracyjnych; z przyczyn obiektywnych proces stosowania prawa administracyjnego nie jest regulowany przez prawo w całości; dzięki temu właściwy organ subiektywizuje w pewnych zakresach proces stosowania sformalizowanego prawa, natomiast zadaniem prawa, jako systemu, jest zapewnienie, aby skutecznie zweryfikowany "produkt” tej zsubiektywizowanej w pewnym zakresie subsumcji normy mieścił się w tym, co stanowi prawo w postaci reguł i zasad - zob. I. Niżnik Dobosz: Formalizm działania administracji publicznej jako niedoskonała pochodna zasady praworzadności, [w:] Administracja publiczna pod rzadami prawa: ksiega pamiatkowa z okazji 70-lecia urodzin prof. zw. dra hab. Adama Błasia, J. Korczak (red), Wrocław 2016, s. 356, http://www.bibliotekacyfrowa.pl/Content/78130/Administracja_publiczna_pod_ rzadami_prawa_Ksiega_pamiatkowa.pdf.

${ }^{84}$ Zob. A. Zdunek, Dopuszczenie jako dowodu w postępowaniu podatkowym materiałów zgromadzonych $w$ innych postępowaniach a zasada czynnego udział u strony $w$ postępowaniu, [w:] M. Popławski (red.): Ordynacja podatkowa: zagadnienia..., s. 153 i 154. 
związanych z okolicznościami sprawy ${ }^{85}$, aby powtórzyć dowód przeprowadzony w innym postępowaniu. Ponowienie określonych czynności dowodowych, przeprowadzonych w toku innego postępowania, będzie konieczne także wówczas, kiedy ocena takich dowodów, dokonana w powiązaniu $\mathrm{z}$ materiałem dowodowym zebranym $\mathrm{w}$ prowadzonym postępowaniu, uniemożliwia jednoznaczne i prawidłowe ustalenie stanu faktycznego w konkretnej sprawie podatkowej ${ }^{86}$. Ten nakaz w równym stopniu dotyczy przypadków uznawanych za dowód decyzji, a jego realizacji nie stoi na przeszkodzie jej szczególny charakter.

Istnienie regulacji prawnych, które formalnie umożliwiają kwestionowanie rozstrzygnięć podjętych przez organy w kwestiach dowodowych, choć w rzeczywistości nie prowadzą do usunięcia skutków materialnych podjętych rozstrzygnięć, niewątpliwie narusza zasadę sprawiedliwości proceduralnej. W szczególności naruszają ją te regulacje, w których nie przewiduje się instrumentów ochrony przed arbitralnością organu. Odmowa przeprowadzenia dowodów przez organ nie wymaga uzasadniania (art. $217 \$ 2$ O.p.) oraz nie podlega zaskarżeniu zażaleniem (art. $236 \$ 1$ O.p.). W ten sposób ustawodawca przesunął badanie jej legalności i zasadności aż do postępowania odwoławczego (art. 237 O.p.). Tymczasem, kontrola instancyjna może się okazać iluzoryczna, wobec zaburzenia zasady dwuinstancyjności, spowodowanego koncentracją w ramach tego samego organu podatkowego (izby administracji skarbowej) funkcji dwóch organów (orzekającego i odwoławczego) ${ }^{87}$.

Odrzucenie wniosków dowodowych zamyka podatnikowi drogę do zastosowania trybu nadzwyczajnego, tj. wznowienia postępowania podatkowego (art. $240 \$ 1$ pkt 5 O.p.), ponieważ dowody przedstawione w nieuwzględnionym wniosku dowodowym nie spełniają przesłanki dowodów istniejących w dniu wydania decyzji i nieznanych organowi, który ją wydał. Odrzucenie wniosków dowodowych nie stanowi także rażącego naruszenia przepisu procesowego jako przesłanka stwierdzenia nieważności decyzji

${ }^{85}$ Zob. wyrok WSA z dnia 11 października 2007 r., I SA/Łd 578/07; http://www.orzeczenia.nsa.gov.pl.

${ }^{86}$ Zob. wyrok WSA z dnia 19 sierpnia 2009 r., I SA/Bk 208/09; http://www.orzeczenia.nsa.gov.pl.

${ }^{87}$ Zgodnie z art. 37 ustawy o Krajowej Administracji Skarbowej w sprawach organizacyjno-finansowych izba administracji skarbowej wraz z podległymi urzędami skarbowymi oraz urzędami celno-skarbowymi stanowi jednostkę organizacyjną, której kierownikiem jest dyrektor izby administracji skarbowej. 
(art. $247 \$ 1$ pkt 3 O.p.). Dopiero na etapie postępowania sądowoadministracyjnego przekroczenie przez organ granic prawa do swobodnej oceny dowodów może zostać zakwalifikowane jako naruszenie przepisów postępowania, jeżeli mogło ono mieć istotny wpływ na wynik sprawy (art. $145 \$ 1$ pkt 1 lit. c) Prawa o postępowaniu przed sadami administracyjnymi ${ }^{88}$ ).

\section{Podsumowanie}

Procedury powinny być maksymalnie godnymi zaufania technikami podejmowania decyzji, których prawomocność gwarantują uprzednio stworzone standardy ${ }^{89}$. Zarówno bezkrytyczne uznawanie decyzji za istotny (rozstrzygający) dowód w postępowaniu podatkowym, jaki i jej dyskredytowanie a priori nie zawsze wydają się słuszne. Z jednej strony organ nie zawsze ma możliwość samodzielnego prowadzenia postępowania dowodowego $^{90} \mathrm{i}$ jest zmuszony do korzystania $\mathrm{z}$ ustaleń dokonanych przez inne organy, ujętych w formie decyzji podatkowych, których wartość dowodowa wynika na równi z rozstrzygnięcia i uzasadnienia. Jednocześnie jednak, za niedopuszczalne należy uznać działania organu, który z powodów oportunistycznych ogranicza się do zebrania decyzji podatkowych, wydanych w innych postępowaniach, i traktuje je jako jedyny i wystarczający dowód w sprawie, tłumacząc swoje postepowanie ustawowym nakazem szybkości i prostoty postępowania oraz trwałością („nienaruszalności”) decyzji ostatecznej.

Działaniu organów pozornie sprzyjają regulacje procesowe, które nie zawierają jednoznacznego unormowania nakazującego stosowanie zasady bezpośredniości w postępowaniu podatkowym, choć poza dyskusją pozostaje, iż nie może być ona realizowana kosztem ograniczania czynnego udziału strony w tym postępowaniu. $Z$ tego powodu wykorzystanie przez organ treści „cudzej” decyzji podatkowej wymaga respektowania reguł, dzięki którym podatnik zyska poczucie, że organ traktuje go uczciwie, niezależnie od tego, czy i z jakim skutkiem skorzysta z procesowych narzędzi ochrony swoich praw. Podatnik ma prawo oczekiwać od organu

${ }^{88}$ Ustawa z dnia 30 sierpnia 2002 r. - Prawo o postępowaniu przed sadami administracyjnymi (Dz.U. z 2017 r., poz. 1369 ze zm.); zob. wyrok NSA z dnia 19 maja 2005 r., sygn. akt: FSK 1721/04; http://www.orzeczenia.nsa.gov.pl.

${ }^{89}$ Zob. J. Helios, Aspekty systemowy..., s. 112.

${ }^{90}$ Przeszkodę dla organu pierwszej instancji stanowią regulacje dotyczące właściwość rzeczowej i miejscowej. 
ostrożności w korzystaniu z tego dowodu, połączonej ze świadomością, że decyzja o znaczeniu danego dokumentu dla wyniku sprawy jest przedmiotem własnej oceny organu, dokonywanej według zasad ogólnych oraz wymagać jasnego i precyzyjnego określenia zakresu wykorzystania dowodu i wyraźnego zakomunikowania tego stronie.

\section{BIBLIOGRAFIA}

Adamiak B., Borkowski J., Kodeks postępowania administracyjnego. Komentarz, Warszawa 2006.

Adamiak B., Borkowski J., Kodeks postępowania administracyjnego. Komentarz, Warszawa 2012.

Adamiak B., Borkowski J., Postępowanie administracyjne i sądowoadministracyjne, Warszawa 2013.

Adamiak B., Borkowski J., Mastalski R., Zubrzycki J., Ordynacja podatkowa. Komentarz, Wrocław 2006.

Babiarz S., Dauter B., Gruszczyński B., Hauser R., Kabat A., Niezgódka-Medek M., Ordynacja podatkowa. Komentarz, Warszawa 2015.

Bochenek W., Kodeks postępowania administracyjnego: komentarz dla praktyków, [w:] A. Mudrecki (red.), Gdańsk 2008.

Borkowski J., Normy prawa materialne i formalne a pojęcie procedury administracyjnej, „Studia Prawno-Ekonomiczne” 1982, t. XXVIII.

Borucka-Arctowa M., Koncepcja sprawiedliwości proceduralnej i jej rola w okresie przemian systemu prawa - analiza teoretyczna i funkcjonalna, [w:] Dynamika wartości w prawie, K. Pałecki (red.), Kraków 1997.

Brzeziński B., Kalinowski M., Olesińska A., Masternak M., Orłowski J., Ordynacja podatkowa: komentarz, Toruń 2007.

Brzeziński B., Kalinowski M., Olesińska A., Masternak M., Orłowski J., Ordynacja podatkowa: komentarz, t. 2, Torun 2007.

Brzeziński B., Kalinowski M., Masternak M., Morawski W., Ordynacja podatkowa: komentarz praktyczny, Gdańsk 2006.

Chauvin T., Prawa stają się prawem: demokratyczne procedury w służbie wartości, [w:] Status jednostki a tendencje rozwojowe prawa, M. Wyrzykowski (red.), Warszawa 2006.

Dolecki H., Ciężar dowodu w polskim prawie cywilnym, Warszawa 1998.

Hanusz A., Dowód z dokumentu w postępowaniu podatkowym, [w:] Ex iniuria non oritur ius. Księga ku czci Profesora Wojciecha Łączkowskiego, A. Gomułowicz (red.), Poznań 2003.

Hanusz A., Postawa faktyczna rozstrzygnięcia podatkowego, Zakamycze, Toruń 2006; Dopuszczalność dowodu $z$ dokumentu w postępowaniu sadowoadministracyjnym [w:] Ksiegga Jubileuszowa Profesora Ryszarda Mastalskiego. Stanowienie i stosowanie prawa podatkowego, W. Miemiec (red.), Wrocław 2009.

Hauser R., Rola przepisów procesowych $w$ realizacji norm materialnego prawa administracyjnego, [w:] Rola materialnego prawa administracyjnego a ochrona praw jednostki, Z. Leoński (red.), Poznań 1998. 
Helios J., Aspekty systemowy i aksjologiczny „procedur”, „Acta Universitatis Wratislaviensis" 2015, nr 3052.

Jędrośka J., Polskie postępowanie administracyjne i sądowoadministracyjne, Wrocław 2003.

Kaczmarek P., Materialne i proceduralne aspekty prawa. Wstęp do rozważań nad przejawami proceduralizacji w prawie europejskim, [w:] Z zagadnień teorii i filozofii prawa. Teoria prawa europejskiego, J. Kaczor (red.), „Acta Universitatis Wratislaviensis” 2005, nr 2760.

Kmieciak Z., Idea sprawiedliwości proceduralnej w prawie administracyjnym (Założenia teoretyczne i doświadczenia praktyki), „Państwo i Prawo” 1994, nr 10.

Kosikowski C., Etel L., Brolik J., Dowgier R., Pietrasz P., Popławski M., Presnarowicz S., Stachurski W., Ordynacja podatkowa, Warszawa 2013.

Kwietko-Bębnowski M., Ordynacja podatkowa: 366 wyjaśnień i interpretacji, Warszawa 2013.

Łaszczyca G. (red.), System prawa administracyjnego procesowego: zagadnienia ogólne, t. I, Warszawa 2017.

Mastalski R., Zubrzycki J., Ordynacja podatkowa. Komentarz, Wrocław 2002.

Mudrecki A. (red.), Kodeks postępowania administracyjnego: komentarz dla praktyków, Gdańsk 2008.

Niesiobędzka M., Sprawiedliwość proceduralna podatków, „Optimum. Studia Ekonomiczne" 2014, nr 4.

Niżnik Dobosz I., Formalizm działania administracji publicznej jako niedoskonała pochodna zasady praworzadności, [w:] Administracja publiczna pod rzadami prawa: ksiega pamiątkowa z okazji 70-lecia urodzin prof. zw. dra hab. Adama Błasia, Wrocław 2016.

Nykiel W., O potrzebie równowagi między uprawnieniami i obowiązkami podatnika oraz organów podatkowych, „Prawo i Podatki” 2005, nr 12.

Nykiel W., Prawo do zapłaty podatku w wysokości wynikającej z przepisów prawa, „Prawo i Podatki" 2008, nr 1.

Ostojski P., Sprawiedliwość proceduralna według ReNEUAL Modelu Kodeksu Postępowania Administracyjnego Unii Europejskiej, „Ruch Prawniczy, Ekonomiczny i Socjologiczny" 2017, nr 1.

Przybysz P., Kodeks postępowania administracyjnego: komentarz, Warszawa 2013.

Rymaszewski M., Zasada sprawiedliwości proceduralnej w postepowaniu podatkowym, „Kwartalnik Prawa Podatkowego” 2013, nr 4.

Służewski J., Postępowanie administracyjne, Warszawa 1982.

Strzelec D., Dowody i postępowanie dowodowe w prawie podatkowym, Warszawa 2015.

Strzelec D., Posługiwanie się jako dowodem materiałami zgromadzonymi w innych postępowaniach, „Monitor Podatkowy” 2008, nr 1.

Strzelec D., Zasada bezpośredniości gromadzenia materiału dowodowego $w$ sprawach podatkowych, „Monitor Podatkowy” 2012, nr 10.

Szopieraj-Kowalska A., Dowody i postępowanie dowodowe według kodeksu postępowania administracyjnego i ordynacji podatkowej, http://kpsw.edu.pl/pobierz/wydawnictwo/ miscellanea/nr2/kowalska_dowody_i_postepowanie.pl. 
Zalewski D., Melezini A., Golec S., Kaźmierski A., Postępowanie podatkowe: 810 wyjaśnień i interpretacji, Warszawa 2013.

Zdunek A., Dopuszczenie jako dowodu w postępowaniu podatkowym materiałów zgromadzonych $w$ innych postępowaniach a zasada czynnego udziału strony $w$ postepowaniu, [w:] Ordynacja podatkowa. Zagadnienia proceduralne, M. Popławski (red.), Białystok 2011.

\begin{abstract}
The author deals with the issue of acceptability of using tax decision as evidence in another tax proceeding. The subject of in-depth deliberations is the question of recognizing a tax decision as an official documents and consequences thereof. In the light of the statutory regulation (Art. 194 of The Tax Ordinance Act) a decision, just like every official document, takes advantage of the presumption of accuracy. This presumption is challengeable with every counter-proof, because factual findings are most important in a tax proceeding (Art. 122 of The Tax Ordinance Act).

Presumption of credibility does not cover the whole content of the decision. In accordance with the predominant tendency in recent years in the case-law of administrative courts, presumption of credibility has been limited to the operative part of the decision. As a result, the factual circumstances included in its justification ceased to be covered with presumption of accuracy. For a tax authority, this change has vital, practical significance. It prevents treating "others"' tax decisions as the only and sufficient proof when formulating settlement and factual justification of "own" decision.
\end{abstract}

Keywords: evidence, tax proceedings, decision 